\title{
Psychological Empowerment: A Key to Boost Organizational Commitment, Evidence from Banking Sector of Pakistan
}

\author{
Ms. Maryam Saeed Hashmi \\ Lecturer, Institute of Business and Management, \\ University of Engineering and Technology, Lahore, Pakistan \\ E-mail: maryamhashmi57@yahoo.com
}

Dr. Imran Haider Naqvi

Manager Research, Development and Operations, ORIC

COMSATS Institute of Information Technology, Lahore, Pakistan

E-mail: drimranhaider@ ciitlahoe.edu.pk

Accepted: May 16, 2012 Published: June 03, 2012

Doi:10.5296/ijhrs.v2i2.1807ＵRL: http://dx.doi.org/10.5296/ijhrs.v2i2.1807

\begin{abstract}
The purpose of this study is to elaborate the role of psychological empowerment in committing employees with organization. This study tested the effect of dimensions of psychological empowerment on organizational commitment in banking sector of Pakistan. Data was gathered from employees working in banks of Pakistan. Results showed the significant effect of all dimensions of psychological empowerment (meaning, competence, self determination and impact) on organizational commitment. This study is a contribution to theory and practice with an increased understanding on importance of psychological empowerment in committing the employees with the organization.
\end{abstract}

Keywords: Psychological Empowerment, Organizational Commitment

\section{Introduction}

The contemporary dynamic business environment is pressurizing organizations to keep their management techniques concurrent with the current challenges. Adopting new management approach has therefore become an imperative for the organizations to meet the demands of 
customers and competitive environment. The present state of affairs has "stimulated a need for employees who can take initiative, embrace risk, stimulate innovation and cope with high uncertainty" (Spreitzer, 1995). In order to achieve this, the business organizations need to have effective personnel supporting their objectives. Therefore, in this era business organizations accept the challenge of providing better-quality services to their internal customers that are employees and promoting practices of employee involvement. Relinquishing top bottom management approach encourages employee organizational commitment and improves individual and organizational performance along with bringing flexibility in the organization (Daft, 2001; Conger \& Kanungo, 1988). High involvement work practices are the source of competitive advantage for business organizations (Dessler, 2007). Most of the human resource practices in the organizations are humanistic in nature and are concerned with behavioral aspects of employees. A number of high involvement work practices are recommended in literature to enhance strategic organizational performance; however most important are self managing teams, shared governance programs, flexible work settings and employee empowerment (Pfeffer \& Viega, 1999; Hiltrop, 1996). Organizations need motivated, responsible and committed employees instead of those who are negligent, sluggish and disloyal. There are different factors accountable for motivated and responsible behaviors of employees and their organizational commitment. Bhatti and Nawab (2011) found role clarity, organizational climate, job satisfaction and employee empowerment as predictors of organizational commitment. One of the major factors affecting psychological empowerment is psychological empowerment, a type of employee empowerment, as it predicts satisfaction, commitment and performance of the employees (Vacharakiat, 2008; Patrick \& Laschinger, 2006; Jha, 2010).

\section{Need to Study Psychological Empowerment as Antecedent of Organizational Commitment in Banking Sector of Pakistan}

The consistent development and better quality are the prerequisites of service business particularly, when environment is under asymmetrical change. The banks in Pakistan are striving to become competitive to address the ever changing customer demand and the global pressures. The government has announced various structural reforms for financial sector of Pakistan to meet the confronted challenges. According to Khattak et al. (2011), the influence of transformation in banking sector of Pakistan is not just confined to the social and economic sphere but it has also affected the psychological sphere of the employees and they are facing burnout. Employee turnover has increased after these changes have taken place. The study conducted by Khan et al. (2011) reports employee retention as one of the biggest problems faced by banks in Pakistan as a result of privatization. An essential way to cope with the problem of employee retention is to understand and analyze the level of organizational commitment of the employees. In the current arena where employee retention has become a significant factor to meet challenges faced by organizations, it is crucial to focus on employee organizational commitment and the factors influencing it.

\section{Literature Review}

Existing literature on the relationship between the psychological empowerment and 
organizational commitment generally consists of the studies conducted in developed countries (Joo \& shim, 2010; Dickson \& Lorenz, 2009; Hancer, 2001; Thomas \& Velthouse, 1990). Emerging and underdeveloped countries have also some contributions in the literature with reference to the relationship between these variables (Jha, 2010; Liu \& Chiu, 2007; Celik, 2001). However, no empirical research is found on the relationship between psychological empowerment and organizational commitment with reference to Pakistan.

\subsection{Organizational Commitment}

Organizational commitment, the spirit of the organization, is essential for the success of any organization because until or unless the employees of any organization are not loyal and sincere to it, it is difficult for organization to meet challenges and pressures faced by it from inner and outer of the organization. Research on organizational commitment covers more than five decades but still continues to be an area of interest. An extensive body of knowledge exists on definitions of the organizational commitment. Organizational commitment is considered both as uni dimensional (Mowday et al., 1979, Wiener, 1982) and multidimensional construct (Allen \& Meyer, 1990, O Reilly \& Chatman, 1986). Luthans (2007) defines organizational commitment as "an attitude reflecting employees' loyalty to their organization and is an ongoing process through which organizational participants express their concern for the organization and its continued success and well-being". According to Allen and Meyer (1991) multidimensional approach to organizational commitment, there are three components of organizational commitment, affective, normative and continuance. Affective commitment refers to the emotional attachment and involvement of an employee in the organization. Normative commitment refers to the obligation of an employee to remain at the organization. It is based on social cognitive theory which states a person receiving benefit is under a strong normative obligation to return it in one way or other. Continuance commitment is calculative in nature and refers to perceived cost of leaving an employee would have to bear if he leaves the organization.

\subsection{Psychological Empowerment}

According to Kanter (1977) there are two different types of empowerment, which are, structural and psychological. Structural empowerment is deemed in the literature as a power sharing concept as it involves delegating decision making authority down the organizational hierarchy. Psychological empowerment belongs to motivational approach of empowerment (Menon, 2001) and according to Conger and Kanungo (1988), the motivational aspect of the empowerment better describes the concept of empowerment. Literature has defined psychological empowerment in different ways. It is defined it as the process of enhancing self efficacy (Conger \& Kanungo, 1988; Yagil, 2006) and a state of increased intrinsic motivation (Thomas \& Velthouse, 1990; Konzak et al., 2000). According to Thomas and Velthouse (1990) model there four cognitions (task assessments) of psychological empowerment are meaningfulness, competence, choice and impact. Spreitzer (1995) defines psychological empowerment in terms of four dimensions: meaning, competence, self determination and 
impact. Meaning cognition refers to a sense of purpose (Spreitzer, 1995) and the congruence or consistency of an individual's beliefs and beliefs and values of the organization (Thomas \& Velthouse, 1990). Impact cognition refers to the degree to which an individual can influence work outcomes and create a difference in the organizations by their work (Thomas \& Velthouse, 1990; Spreitzer, 1995; Spreitzer et al., 1997). Competence cognition refers to self efficacy and capacity an individual to perform skillfully (Spreitzer, 1995). Self determination cognition refers to autonomy or freedom in initiation and continuation of work behaviors and processes (Spreitzer, 1995). According to Spreitzer et al., (1997) an employee must experience all four cognitions of psychological empowerment and if all these are not present the feeling of psychological empowerment is incomplete. The current study uses the Spreitzer's (1995) terminology of four cognitions of psychological empowerment and examines psychological empowerment as a determinant of organizational commitment for the employees in banking sector of Pakistan.

\subsection{Relationship between Psychological Empowerment and Organizational Commitment}

Empowerment is found to be positively correlated with all three components of organizational commitment (John, 2005). According to Patrick and Laschinger (2006) increasing psychological empowerment in the workplace increases the employee commitment with the organization and its goals. Joo and Shim (2010) found psychological empowerment as predictor of organizational commitment. Other researchers (Liu \& Chiu, 2007; Liden et al., 2000; Vacharakiat, 2008) also found the positive relationship between psychological empowerment and organizational commitment in their studies. The present study identifies an association psychological empowerment and organizational commitment of the employee on the basis of literature review.

\section{Research Problem}

Literature confirms a significant relationship of psychological empowerment with organizational commitment. As this study selected the banking sector of Pakistan, during the preliminary investigation it collected facts that turnover in banking sector has been at its peak during the recent decade. Low organization commitment among bankers of all cadres was reported as a complaint that all banks were facing. As literature indicates that psychological empowerment play significant role in persuading an employee to acquire good degree of organizational commitment, the study developed interest in exploring do psychological empowerment commits bankers in Pakistan. If yes, how much?

Based upon literature review, this study develops the following hypothesis:

$\mathrm{H}_{1}$ : Psychological empowerment (meaning, competence, self determination and impact) positively and significantly predict organizational commitment.

\section{Research Methodology}

This research is a non contrived study conducted in field and studies the relationship between 
psychological empowerment and organizational commitment in banks of Pakistan (Lahore, Sargodha, Karachi and Islamabad). Unit of analysis of this study are employees working in banking sector of Pakistan. The study is cross sectional as the data is collected in one point in time from individual to describe the relationship between the variables at that particular time. Sample size for this study is 384 and sample was selected through simple random sampling. The study has used survey approach for data collection. Response rate was $80.7 \%$ as 310 out of 384 questionnaires were retrieved. The study has used Spreitzer's (1995) scale to measure psychological empowerment and Meyer and Allen (1991) scale to measure organizational commitment. Validity and reliability was tested before analyzing the data for relationship between variables. The value of Cronbach alpha was 0.892 . The study used exploratory factor analysis to test validity of instrument. The study found that factor loading for all dimensions of variables after extraction was above 0.7 which ensures the validity of the instrument. The study has used 7 point Likert Scale from strongly agree to strongly disagree to measure responses.

\section{Data Analyses and Results}

The study ha used SPSS version 17 for data analyses. The study has used descriptive statistics to measure characteristics of sample. To find out the relationship between variables, the study has used step wise regression. Descriptive statistics for sample showed that majority of respondents were from gender male $(\mathrm{n}=194$, that is $62.6 \%$ ), belonged to age group of 36-45 ( $\mathrm{n}=94$, that is $30.3 \%)$, had qualification of Master Degree $(\mathrm{n}=177$, that is $57.1 \%)$, were having job tenure of 10 or more years $(n=151$, that is $48.7 \%)$ and belonged to middle management position $(\mathrm{n}=161$, that is $51.9 \%)$. Descriptive statistics for psychological empowerment at their job (mean= 5.42, S.D = 1.042) showed an above average score. The score of employees on all four dimensions i.e. meaning (mean= 5.32, S.D = 1.032), competence $($ mean $=5.17$, S.D = 1.042), self determination and impact (mean= 5.29, S.D = 1.168) was above average. The results with respect to dimensions of psychological empowerment indicated that employees were experiencing all four dimensions of psychological empowerment at their job. Descriptive statistics for organizational commitment have shown that employees score on organizational commitment was above average (mean= 4.21 , S.D $=0.700$ ). The results with respect to components of organizational commitment showed that employees score were highest for affective commitment (mean= 5.18, S.D = 1.124) followed by the score on normative commitment (mean= 5.01, S.D $=01.093$ ) however, employees scored least on continuance commitment (mean=4.14, S.D =1.045). The results of stepwise regression are given below:

Table 1.1

Model Summary

\begin{tabular}{|l|l|l|l|}
\hline $\mathrm{R}$ & $\mathrm{R}^{2}$ & Adjusted $\mathrm{R}^{2}$ & Standard Error of Estimate \\
\hline $.914^{\mathrm{e}}$ & .835 & .832 & .386 \\
\hline
\end{tabular}

Table 1.2 
ANOVA

\begin{tabular}{|l|l|l|l|l|l|}
\hline Model & $\begin{array}{l}\text { Sum } \\
\text { Squares }\end{array}$ & Df & Mean Square & F & Sig. \\
\hline Regression & 228.623 & 5 & 45.725 & 306.679 & $.000^{\mathrm{e}}$ \\
\hline Residual & 45.325 & 305 & .149 & & \\
\hline Total & 273.948 & 310 & & & \\
\hline
\end{tabular}

Table 1.3

\section{Coefficients}

\begin{tabular}{|l|l|l|l|l|l|}
\hline & $\begin{array}{l}\text { Unstandardi } \\
\text { zed } \\
\text { coefficient } \\
\text { (B) }\end{array}$ & $\begin{array}{l}\text { Unstandardi } \\
\text { zed } \\
\text { coefficient } \\
\text { (Std. Error) }\end{array}$ & $\begin{array}{l}\text { Standardiz } \\
\text { ed } \\
\text { coefficients } \\
\text { (Beta) }\end{array}$ & Sig. \\
\hline (Constant) & .140 & .136 & & 1.026 & .306 \\
\hline Meaning & .359 & .033 & .388 & 10.851 & .000 \\
\hline Impact & .308 & .030 & .334 & 10.213 & .000 \\
\hline Self Determination & .234 & .039 & .243 & 5.954 & .000 \\
\hline Competence & .146 & .036 & .160 & 4.087 & .000 \\
\hline
\end{tabular}

a. Dependent Variable: Organizational Commitment

Table 1.1 indicates that all four dimensions collectively explain $83.5 \%$ of variance in organizational commitment. Table 1.2 is indicating that $\mathrm{F}$ value is highly significant (Sig.= 0.00 ) which ensures validity of overall model. Table 1.3 indicates that the unstandardized regression coefficients (B) for predicting organizational commitment from dimensions of psychological empowerment. The highest unstandardized coefficient for predicting organizational commitment in meaning $(\beta=0.359)$ followed by impact $(\beta=0.308)$ then self determination dimension of psychological empowerment $(\beta=0.234)$, then competence dimension of psychological empowerment $(\beta=0.146)$. The standard errors of the estimates are less 1 which means that this study is confident about its results. . Table 1.3 is also indicating the relative importance of each dimension of psychological empowerment and job satisfaction in predicting organizational commitment by its respective $t$ value. It is well evident that importance of meaning dimension of psychological empowerment in predicting organizational commitment is highest.

\section{Discussion}

Bankers in Pakistan showed a slightly above average response on organizational commitment and above average response on psychological empowerment. However, the regression analyses indicated that all dimensions of psychological empowerment (meaning, competence, self determination and impact) significantly and positively influence level of commitment for employee working in banks of Pakistan. Based upon findings, this study has drawn some understanding. First, when employees perceive their tasks meaningful and feel that their individual and organizational goals are well aligned, their level of organizational commitment is enhanced. Second, when employees feel that they have autonomy in initiation and continuation of their job task, their organizational commitment is enhanced. If employees 
have to ask from senior management to perform their tasks, they feel themselves dependent on others. This feeling in them can reduce their level of commitment with organization. Third, when employees perceive that they have necessary skills and competencies to perform their job well, their level of organizational commitment may not go up. Perception of competence in employees may enhance their level of self efficacy and they may consider that they are able to get better job opportunities hence their level of commitment is not strongly predictable by competence dimension of psychological empowerment. Fourth, when employees perceive that they are contributing in organizational goal achievement and are influencing their work outcomes, their feeling of organizational commitment enhances. Employees having high level of all four dimensions of psychological empowerment are emotionally attached with organization and feel obligation to remain with organization.

\section{Conclusion}

The current study identified an essential role of psychological empowerment in committing employees with banks in Pakistan. Findings of this study are not only helpful for banks in Pakistan but these can be instrumental for other organizations for arousing the feelings of commitment with organization in employees. Organizational commitment is strength of any organization. Psychological empowerment plays a significant role in committing employees with organization. Perception of meaningful tasks, autonomy in work, feeling of skillfulness in performing tasks and perception of impacting work outcomes in employees lead to high level of commitment of employees with organization. It is a common phenomenon from the ages back that if you have to get something, you have to invest something. Therefore, organizations must provide such working environment in which employees not only feel psychologically empowered but also become satisfied with their job which will ultimately lead to high level of organizational commitment.

\section{Limitations of the Study}

This was a cross sectional study and the results of this study were limited to the time frame in which data was gathered. Future researchers can analyze the relationship between variables by conducting longitudinal study. Data of the study was collected only from Lahore, Sargodha and Karachi. The study includes only those predictors of organizational commitment which are in scope of this study. Future researchers can include the other predictors of organizational commitment which this study has not taken into consideration. 


\section{References}

Allen, N.J., \& Meyer, J.P. (1990). The measurement and antecedents of affective, continuance and normative commitment to the organizations. Journal of Occupational Psychology, $63,1 \quad 18$.

Allen, N.J., \& Meyer, J.P. (1991). A three-component conceptualization of organizational commitment. Human Resource Management Review, 1, 61-98.

Arocas, R, L., \& Camps, J. (2008). A model of high performance work practices and turnover intention. PersonnelReview, 1, 26-46.

Corsun, D. \& C. Enz (1999). Predicting psychological empowerment among service workers: The effect of support based relationships. Human Relations, 52(2), 205-224.

Conger, J.A. \& Kanungo, R.N. (1988). The empowerment process: integrating theory and practice.Academy of Management Review, 13, 471-82.

Daft, R.L. (2001), OrganiZation Theory and Design, Southwestern, Cincinnati, OH. Dessler, G., (2007) Human resource management. New Delhi: Prentice Hall of India Private Limited.

Dessler , G., (2007) Human resource management. New Delhi: Prentice Hall of India Private Limited.

Dickson, E.K., \& Lorenz, A. (2009). Psychological empowerment and job satisfaction of temporary and part-time nonstandard workers: A preliminary investigation. Institute of Behavioral and Applied Management.

Hiltrop, J. M.A. (1996). A framework for diagnosing human resource management practices. European Management Journal, 14, 243-54.

Houghton, J.D., \& Yoho, S.K. (2005). Toward a contingency model of leadership and psychological empowerment: when should self-leadership be encouraged? Journal of Leadership an Organizational Studies, 11(4), 65-83.

Hancer, M. (2001.) An analysis of psychological empowerment and job satisfaction for restaurant employees. Human Nutrition and Food Management.

Johns, R. (2005). Determinants of organizational commitment among U.S. workers. Unpublishedmaster's thesis, Duquesne University.

Joo, B., \& Shim, J. H. (2010). Psychological empowerment and organizational commitment: The moderating effect of organizational learning culture. Human Resource Development 
International, 13(4), 425-441.

Jha, S. (2010). Influence of psychological empowerment on affective, normative and Continuance commitment: A study in Indian it industry. International Journal of Organizational Behavior, 15 (1), 53-72.

Khattak, J., Khan, M., Haw, A., Arif, M., Minhas, A. (2011). Occupational stress and burnout in Pakistan's banking sector. African Journal of Biotechnology,5(3), 810-817.

Khan, M. A., Kashif Ur, R., Ijaz Ur, R., Safwan, N., \& Ahmad, A. (2011). Modeling link between internal service quality in human resources management and employees retention: A case of Pakistani privatized and public sector banks. African Journal of Business Management, 5(3), 949-959.

Konczak, L.J. Stelly, D.J., \& Trusty, M.L. (2002). Defining and measuring empowering leader behaviors:, development of an upward feedback instrument. Education and Psychological Measurement, 60(2), 301-313.

Liu A. M. M., Chiu, W. M., \& Fellows, R. (2007). Enhancing commitment through work empowerment. Engineering, Construction, Architectural Management, 14(6), 568-580.

Mowday, R. T., Steers, R. M., \& Porter L. W. (1979). The measurement of organizational commitment. Journal of Vocational Behavior, 14,224-227.

O Reilly, C., \& Chatmen, J. (1986). Organizational commitment and psychological attachment: The effects of compliance, identification and internalization on pro social behavior. Journal of $\quad$ Applied Psychology, 71, 429499.

Meyer P. J., Allen, J. N. (1984). Testing the side-bet theory of organizational commitment: Some methodological considerations. Journal of Applied Psychology 69, 372-378.

Menon, S. R. (2001). Employee empowerment: An integrative psychological approach. Applied Psychology: An International Review, 50(1), 153-180.

Patrick, A., \& Laschinger, H.K.S. (2006). The effect of structural empowerment and perceived organizational support on middle level nurse managers' role satisfaction. Journal of Nursing Management, 14, 13-22.

Pfeffer, J., \& Viega, J.F. (1999). Putting people first for organizational success. Academy of Management Executive, 13, 38-48.

Porter L. W., Steers, R. M., Mowday R. T., Boulian, P. V. (1974). Organizational commitment, job satisfaction and turnover among psychiatric technicians. Journal of Applied 
Psychology 59, 603-609.

Spreitzer, G. M., Kizilos, M.A., \& Nason, S.W. (1997). A dimensional analysis the relationship between psychological empowerment and effectiveness, satisfaction and strain. Journal of Management, 23(5),679-704.

Spreitzer, G. M. (1995). Psychological empowerment in the workplace: Dimensions, measurement, and validation. .Academy of Management Journal, 38(5), 1442-1465.

Thomas, K. W. and Velthouse, B.A. (1990). Cognitive elements of empowerment. Academy of Management Review, 15 (4), 666-81.

Vacharakiat, M. (2008). The relationships of empowerment, job satisfaction, and organizational commitment among Filipino and American registered nurses working in the USA. (Unpublished doctoral thesis). University of George, Mason.

Wiener, Y. (1982). Commitment in organizations: A normative view. Academy of ManagementReview. 7(3), 418-428. 